\title{
Pemberdayaan Masyarakat Muslim Berbasis Lingkungan
}

\author{
Ihsanti Saridera* \\ Jurusan Pengembangan Masyarakat Islam UIN Sunan Gunung Djati Bandung \\ *Email : ihsantis@yahoo.com
}

\begin{abstract}
This research is to find out the efforts of the community of Sukamukti Subdistrict, Banyuresmi, GarutRegency in empowering the environment-based community, a strategy carried out by the Kiwang Kreatif Group in the utilization of Eceng Gondok. waste, and its impact on community welfare and environmental cleanliness. This research uses descriptive analysis method, data collection, observation, interview and document study. The results showed that the strategy carried out by the Kiwang Kreatif Group in utilizing Hyacinth was included with the assistance of local government officials who contributed to empowering the environment at Lake Situ Bagendit through three stages, namely training, mentoring and mentoring in the utilization of waste from the Eceng plant Mumps, which is supported by a budget or capital in carrying out this activity. The Kiwang Kreatif group teaches about the awareness of each individual, especially in the Sukamukti Village community, about the importance of maintaining environmental hygiene so that it looks more bealthy and maintained its beauty that is not spared from using the Eceng Gondok, plant to become an item that has selling value. The method of training, mentoring and mentoring through the use of Hyacinth waste carried out by the Kiwang Kreatif Group was very accepted by the people in Sukamukti Village because it can improve welfare, regulate a clean environment and increase the creativity of the community.
\end{abstract}

Keywords: Empowerment, Society, Environment

\begin{abstract}
ABSTRAK
Penelitian ini untuk mengetahui upaya masyarakat Desa Sukamukti Kecamatan Banyuresmi Kabupaten Garut dalam memberdayakan masyarakat berbasis lingkungan, strategi yang dilakukan Kelompok Kiwang Kreatif dalam pemanfaatan limbah tumbuhan Eceng Gondok, dan dampaknya terhadap kesejahteraan masyarakat dan kebersihan lingkungan. Penelitian ini menggunakan metode deskriptif analisa, pengumpulan data, observasi, wawancara dan studi dokumen. Hasil penelitian menunjukkan bahwa strategi yang dilakukan oleh Kelompok Kiwang Kreatif dalam pemanfaatan Eceng Gondok yang disertakan dengan adanya bantuan dari pihak aparat pemerintah
\end{abstract}

Diterima: Pebruari 2018. Disetujui: April 2018. Dipublikasikan: Juni 2018 


\section{Saridera}

setempat yang ikut berkontribusi dalam memberdayakan lingkungan di Danau Situ Bagendit melalui tiga tahapan yaitu pelatihan, pembimbingan dan pendampingan dalam pemanfaatan limbah dari tumbuhan Eceng Gondok, yang didukung dengan adanya anggaran atau permodalan dalam pelaksanaan kegiatan ini. Kelompok Kiwang Kreatif mengajarkan tentang kesadaran setiap individu terutama pada masyarakat Desa Sukamukti tentang pentingnya untuk menjaga kebersihan lingkungan agar terlihat lebih teurus dan terjaga keindahannya yang tidak luput dari memanfaatkan tumbuhan Eceng Gondok menjadi sebuah barang yang mempunyai nilai jual. Metode pelatihan, pembimbingan dan pendampingan melalui pemanfaatan limbah Eceng Gondok yang dilakukan oleh Kelompok Kiwang Kreatif ini sangat diterima oleh masyarakat di Desa Sukamukti karena dapat meningkatkan kesejahteraan, tertatanya lingkungan yang bersih dan meningkatkan kekreatifan warga masyarakat.

Kata Kunci: Pemberdayaan, Masyarakat, Lingkungan

\section{PENDAHULUAN}

Situ Bagendit adalah suatu wilayah yang memiliki pesona alam yang begitu indah dan sangat menarik untuk dikunjungi bagi wisatawan yang mencintai keindahan alam. Situ Bagendit merupakan sebuah danau yang luas yang dikelilingi oleh berbagai macam tumbuhan hijau disekitarnya yang ke elokan dari danau Situ Bagendit ini sangatlah memikat para wisatawan yang telah berkunjung.

Situ Bagendit terletak di Desa Bagendit Kecamatan Banyuresmi Kabupaten Garut. Situ Bagendit merupakan objek wisata alam berupa danau dengan batas administrasi disebelah Utara berbatasan denan Desa Banyuresmi, disebelah Timur berbatasan dengan Desa Binakarya, dan disebelah Barat berbatasan dengan Desa Sukamukti.

Betapa kayanya Negara Indonesia ini dengan pesona alamnya yang dapat memanjakan mata kita sehingga menyadarkan kita akan ketakjuban Ciptaan Allah SWT. Kekayaan alam di Situ Bagendit terutama pada danaunya, selain ada pesona yang indah dari setiap mata yang memandang juga terdapat ikan-ikan di dalamnya dan berbagai tumbuhan hijau disekitar danau terutama diatas perairan danau yang terdapat jenis tumbuhan air mengapung, daunnya berwarna hijau dan kadang-kadang berakar di dalam tanah, tingginya sekitar 0,4 - 0,8 meter, tidak mempunyai batang, daunnya tunggal dan berbentuk oval, ujung dan pangkalnya meruncing, pangkal tangkai daun menggelembung dari pemaparan jenis tumbuhan hijau ini bernama Eceng gondok.

Tumbuhan Eceng gondok sangat pesat pertumbuhannnya yang menjadi sebuah masalah dalam keindahan lingkungan sekitar Situ Bagendit yang akibat dari maraknya tumbuhan Eceng gondok ini menjadikan keindahan dari sekitaran danau terbungkus oleh tumbuan berjenis Eceng gondok karena jenis tumbuhan 
ini memiliki pertumbuhan yang sangat cepat, sehingga perlu adanya sebuah pemberdayaan dari masyarakat sekitar Situ Bagendit untuk mengantisipasikan dari adanya masalah tersebut.

Pemberdayaan berasal dari kata "daya" yang mendapat awalan ber menjadi kata "berdaya" artinya memiliki atau mempunyai daya. Daya artinya kekutan, berdaya artinya memiliki kekuatan. Kata "berdaya" apabila diberi awalan pe- dengan mendapat sisipan - $m$ - dan akhiran - an menjadi "pemberdayaan" artinya membuat sesuatu menjadi berdaya atau mempunyai daya atau mempunyai kekuatan. Sehingga pemberdayaan dapat membebaskan seseorang dari kendali yang kaku, dan memberi orang tersebut kebebasan untuk bertanggungjawab terhadap ideidenya, keputusan-keputusannya dan tindakan-tindakannya. Berikutnya guna memperkuat upaya pemberdayaan perlu dilakukan pemberdayaan pada organisasi, yang pada akhirnya diharapkan akan bermakna bagi pemberdayaan masyarakat secara keseluruhan, sehingga masyarakat bias merasa sejahtera. Pemberdayaan masyarakat pada hakekatnya tidak hanya ditujukan secara individual, akan tetapi juga secara kolektif (Individual Self Empowerment maupun collective Self Empowerment), sebagian dari akualisasi eksisitensi manusia.

Pemberdayaan tertuju pada beberapa bidang yang salah satunya yaitu pemberdayaan lingkungan yang memfokuskan tentang upaya-upaya untuk menjadikan lingkungan sehat. Sudah selayaknya manusia menjaga lingkungan hidup dengan penuh tanggungjawab. Lingkungan hidup adalah kesatuan ruang dengan semua benda daya, keadaan dan makhluk hidup, termasuk manusia dan prilakunya yang tentunya mempengaruhi alam itu sendiri, kelangsungan berkehidupan dan kesejahteraan manusia serta makhluk hidup lainnya.

Kesejahteraan terhadap lingkungan tidak menyangkut soal kesehatan saja tapi juga soal kebersihannya karena lingkungan yang bersih merupakan awal hidup sehat, walaupun demikian kesadaran untuk menjaga kebersihan lingkungan pada masyarakat kita sangat kurang, kebiasaan-kebiasaan serba asal masih terlalu melekat dalam kehidupan. Selain untuk mendapat derajat kebersihan yang lebih baik, lingkungan bersih juga bisa melahirkan sebuah kreatifitas lebih, dan ide-ide cemerlang, keindahdan tetap terjaga tidak terganggu oleh kehadiran dari tumbuhan Eceng gondok yang jumlahnya sangat banyak. Hardoyono, F.(2009) mengatakan, kesadaran untuk menjaga lingkungan penting bagi kehidupan.

Beberapa penelitian terdahulu yang relevan antara lain pemberdayaan masyarakat melalui pengelolaan sampah oleh Bank Sampah Pelita Harapan (Jastam, 2015), Bank ini terletak di Kelurahan Ballaparang dapat meningkatkan pembangunan wilayah dengan memberdayakan masyarakat untuk mengelola sampah. Sejumlah manfaat antara lain manfaat ekologis, ekonomis maupun secara spiritual. Yazid, Y. \& Alhidayatillah, N. (2017), pemberdayaan lingkungan 


\section{Saridera}

perlu melibatkan masyarakat. Pemberdayaan lingkungan merupakan cita-cita bersama sehingga harus diciptakan secara bersama-sama. Partisipasi masyarakat dimulai dari kepedulian masyarakat terhadap informasi-informasi lingkungan, baik manfaat maupun dampak. Fua, J.L. \& Wekke, I.S. (2017), dalam pendekatan dakwah pemberdayaan dapat dilakukan melalui kegiatan ceramah keagamaan dan khutbah jumat. Prakarsa da'i menyampaikan topik lingkungan dalam dakwah merupakan langkah yang tepat untuk mengintegrasikan kehidupan keseharian para pemeluk agama dengan aktivitas yang ditekuninya. Rihlah Nur Aulia, R.N. (2017) tentang pengelolaan lingkungan berbasis pesantren. Pesantren dapat menetapkan program kurikulum dan pendidikan berorientasi lingkungan.

Penelitian sejenis lainnya terkait dengan pemberdayaan masyarakat diteliti oleh Widjajanti (2011) tentang Model Pembedayaan Masyarakat. Hasilnya menunjukkan bahwa ada dua pola cara peningkatan keberdayaan masyarakat, yaitu, pertama pola yang terdiri dari dua tahapan untuk keberdayaan, dan kedua pola yang menunjukkan bahwa untuk meningkatkan keberdayaan diperlukan tiga proses. Terdapat korelasi dimana semakin tinggi proses pemberdayaan akan dapat menciptakan keberdayaan masyarakat.

Terkait dengan pemberdayaan masyarakat muslim secara spesifik diteliti oleh Nurjamilah (2016) yang melakukan penelitian berbasis masjid. Hasil penelitian menunjukkan bahwa bentuk pemberdayaan yang dilakukan meliputi pemberdayaan dalam aspek spiritual, social, pendidikan, politik, ekonomi, dan pertahanan dengan cara menyediakan akses melalui pembangunan masjid, pasar sekitar masjid, dan melatih pasukan pertahanan.

Penelitian lainnya dilakukan juga oleh Mustangin, Kusniawati, Islami, Setyaningrum, dan Prasetyawati (2017) tentang Pemberdayaan Masyarakat Berbasis Potensi Lokal Melalui Program Desa Wisata di Desa Bumiaji. Hasil penelitian menunjukkan bahwa pemberdayaan masyarakat Desa Wisata di Bumiaji dilakukan dengan mengoptimalkan program desa wisata yang menjadi potensi masyarakat local.

Terkait dengan permasalahan di sekitar Situ Bagendit, memunculkan sebuah kreatifitas dan ide-ide cemerlang dari sekumpulan atau kelompok yang bernama Kiaralawang Kreatif (Kiwang Kreatif), wadah bagi masyarakat sekitar Desa Sukamukti Kecamata Banyuresmi Kabupaten Garut untuk menuangkan ide-ide atau kreasi dari adanya sebuah masalah yang khususnya dalam bidang sumber daya lingkungan dalam sebuah kasus adanya pencemaran lingkungan secara alami di sekitar danau Situ Bagendit. Maraknya jumlah dari tumbuhan hijau Eceng gondok membuat masyarakat merasa terganggu akan kehadiran dari tumbuhan tersebut khususnya masyarakat yang lokasinya dekat dengan Situ Bagendit.

Penelitian memiliki fokus: bagaimana upaya yang dilakukan masyarakat sekitar Kiaralawang dalam pemberdayaan masyarakat berbasis lingkungan? 
Bagaimana strategi Kelompok Kiwang Kreatif dalam pemanfaatan limbah dari tumbuhan Eceng Gondok? Bagaimana dampak kegiatan Kelompok Kiwang Kreatif terhadap kebersihan lingkungan di Desa Sukamukti?

Metode yang digunakan dalam penelitian ini adalah metode deskriftif, dengan menganalisis hasil pengumpulan data melalui observasi dan wawancara dengan Juru Kunci sekretaris Kelompok Kiwang Kreatif, Kampung Kiaralawang, Desa Sukamukti, Kecamatan Banyuresmi, Kabupaten Garut.

\section{HASIL DAN PEMBAHASAN}

Teori yang dijadikan landasan dalam penelitian ini adalah teori pemberdayaanpengertian tentang pemberdayaan yang dapat diartikan pembangunan. Karena pemberdayaan adalah pembangunan yang berpusat pada rakyat. Hal ini di dasarkan pada pandangan Soetomoyang berpendapat bahwa pembangunan dapat di tafsirkan sebagai upaya membangun power oleh suatu masyarakat, antara lain dalam peningkatan kemampuan untuk mengubah kondisi masa depan. Dengan demikian, power dapat digambarkan sebagai sumber daya dan hasil dari proses pembangunan itu sendiri. Berdasarkan pemikiran tersebut, power dalam proses pembangunan dapat diartikan sebagai penguasaan atau kontrol terhadap sumber daya, pengelolaan sumber daya dan hasil serta manfaat yang diperoleh (Soetomo, 2006:404).

Dengan demikian pemberdayaan adalah sebuah proses dan tujuan. Sebagai proses, pemberdayaan adalah serangkaian kegiatan untuk memperkuat kekuasaaan atau keberdayaan kelompok lemah dalam masyarakat, termasuk individu-individu yang mengalami masalah kemiskinan. Sebagai tujuan, maka pemberdayaan menunjuk pada keadaan atau hasil yang dicapai oleh sebuah perubahan sosial, yaitu masyarakat yang berdaya, memiliki kekuasaan atau mempunyai pengetahuan dari kemampuan dalam memenhi kebutuhan hidupnya baik yang bersifat fisik, ekonomi maupun sosial seperti memiliki kepercayaan diri, mampu menyampaikan aspirasi, mempunyai mata pencaharian, berpartisipasi dalam kegiatan sosial, dan mandiri dalam melaksanakan tugastugas kehidupannya. Pengertian pemberdayaan sebagai tujuan seringkali digunakan sebagai indikator keberhasilan pemberdayaan sebagai sebuah proses (Suharto, 2005: 56-60).

Kekuatan dalam konsep pemberdayaan menunjukkan kemampuan untuk menjangkau dan mengontrol sumber-sumber dan orang-orang. Konsep yang berkaitan dengan pemberdayaan adala stratifikasi, yang menunjukkan cara-cara bagaimana kelompok-klompok orang dalam masyarakat dibeda-beda satu sama lain dan ditempatkan dalam susunan hierarkis. Sertifikasi dan hierarkis menghambat iindividu-individu dan kelompok-kelompok untuk menjangkau 


\section{Saridera}

sumber-sumber yang berharga, kekuatan dan kontol atas mereka sendiri (Fachrudin, 2012: 68).

Pandangan manusia terhadap lingkungan (ekosistem) dapat dibedakan pada dua cara pandang, yakni pandangan yang bersifat imanen (holistik) dan pandangan bersifat transenden. Dalam perspektif imanen atau holistik, posisi alam meskipun terpisah dengan manusia, namun memiliki relasi fungsional dengan faktor biofisik (hewan, tumbuhan, sungai, laut dan gunung) sehingga membentuk kesatuan sosio-biofisik. Sedangkan bagi manusia yang berpandangan transenden, menempatkan lingkungan berada pada posisi yang jauh, meskipun menyadari bahwa alam dan manusia berhubungan erat, sehingga manusia merasa terpisah dari lingkungannya. Bagi manusia seperti ini, lingkungan atau alam sekitar hanya dianggap sebagai sumber daya alam yang bebas dieksploitasi demi kepentingan umat manusia (Muhyiddin, 2010: 6-17).

Kesadaran lingkungan menurut M.T Zen (1985:12) adalah teori lingkungan menurut Mudaham Taufick Zen bahwa usaha melibatkan setiap warga dalam menumbuhkan dan membina kesadaran untuk melestarikan lingkungan berdasarkan tata nilai, dari pada lingkungan itu sendiri dengan filsafat hidup secara damai dengan alam lingkungannya.Untuk mengelola lingkungan hidup yang lebih baik, maka bisa dilakukan dengan membudayakan masyrakat. Membudayakan masyarakat untuk ikut mengelola lingkungan mungkin adalah cara yang efektif untuk menyelamatkan lingkungan karena masyarakat adalah juga prusak lingkungan itu sendiri. Dengan begitu membuat mreka berubah cara mengelola lingkungan, mka ekosistem akan terjaga. Mengikutsertakan masyarakat dalam upaya pengelolaan lingkungan yang berkelanjutan akan memberikan hasil positif dimasa depan (Neolaka, 2008: 19).

Apabila manusia mengurus dan mengelola alam lingkungan dengan berbagai kekayaan yang tersedia ini dengan sebaik-baiknya, seadil-adilnya, maka kebaikan itu akan dinikmati manusia secara awet dan lestari. Tetapi sebaliknya, apabila pengurusan alam ini tidak baik, boros dan serampangan, tidak adil dan tidak seimbang dalam melakukan eksplorasi melewati batas dalam memperlakukan alam lingkungannya, niscaya azab Allah SWT dan malapetaka akan datang kepada manusiaakibat perbuatannya (Mundiatun, 2015: 279).

Unsur pokok dalam prinsip etika lingkungan hidup ada dua, yang pertama komunikasi moral tidak hanya dibatasi pada komunitas sosial, melainkan mencakup komunitas ekologis seluruhnya. Kedua, hakikat manusia bukan hanya sebagai makluk sosial, melainkan juga makhluk ekologis. Prinsip-prinsip ini dimaksudkan sebagai pedoman untuk melakukan prubahan kebijakan sosial, politik, dan ekonomi untuk lebi berpihak pada lingkungan hidup dan dapatt mengatasi permasalahan yang terjadi pada lingkungan sekarang ini. Semua teori etika lingkungan hiidup mengakui bahwa alam semesta perlu dihormati. Pada teori antroposentrisme menghormati alam karena kepentingan manusia 
bergantung pada kelestarian dan integritas alam. Sedangkan pada teori biosentrisme dan ekosentrisme beranggapan bahwa manusia mempunyai kewajiban moral untuk mengargai alam semesta dengan segala isinya karena manusia adalah bagian dari alam dan karena alam mempunyai nilai pada dirinya sendiri (Sonny, 2010: 167).

Penelitian ini dilakukan di Desa Sukamukti,yang merupakan wilayah pemekaran dari Desa Sukaratu, seiring dengan perkembangan waktu jumlah penduduk yang bertambah setiap tahunnya, serta kebutuhan akan pelayanan masyarakat yang terus meningkat, sehingga tokoh-tokoh masyarakat yang berada di lingkungan wilayah Sukamukti memperjuangkan pembentukan pemekaran Desa baru melalui proses pemekaran Desa yang disebabkan jumlah penduduk yang melebihi jumlah normal di desa-desa sekitarnya dan letak Sukamukti yang terpisah.

Desa Sukamukti terletak di Kecamatan Bayuresmi, Kabupaten Garut. Di Desa ini terdapat sebuah kelompok yang bernama Kelompok Kiwang Kreatif yang memfokuskan pemberdayaan masyarakat pada lingkungannya, agar lingkungan tertata dengan baik dengan membasmi lalu mengolah sebagaian dari tumbuhan Eceng Gondok menjadi sebuah karya tangan yang memiliki nilai jual.

Kelompok Kiwang Kreatif yang beranggotakan dari kaum hawa, di bangun berdasarkan adanya sebuah masalah lingkungan sekitar Danau Situ Bagendit, kelompok ini didirikan oleh sekumpulan mahasiswa Garut yang melihat sekitar danau terselimbuti tumbuhan Eceng Gondok yang membuat resah warga sekitar sehingga dari permasalahn inilah jiwa dan hatinya terpanggil untuk membangun sebuah kelompok untuk membasmi sebagian tumbuhan Eceng Gondok tanpa harus membuangnya dengan percuma yaitu melalui pemanfaatan limbah tumbuhan Eceng Gondok. Dari sinilah lahirlah sebuah kelompok yang bernama Kiwang Kreatif.

Hasil penelitian ini menemukan metode pelatiham, pembimbingan dan pendampingan yang diajarkan oleh Kelompok Kiwang Kreatif kepada warga masyrakat Kampung Kiaralawang, Desa Sukamukti, Kecamatan Banyuresmi, Kabupaten Garut sebagai salah satu upaya dan strategi pemanfaatan limbah dari tumbuhan Eceng Gondok menjadi sebuah barang yang bernilai.

\section{UpayaMasyarakat Desa Sukamukti Memberdayakan Lingkungan}

Upaya adalah usaha untuk menyampaikan maksud, akal dan ikhtiar. Upaya merupakan segala sesuatu yang bersifat mengusahakan terhadap sesuatu hal supaya dapat lebih berdaya guna dan berhasil guna sesuai dengan maksud, tujuan dan fungsi serta manfaat suatu hal tersebut dilaksanakan (Poerwadarminta, 1991: 574).

Dengan pemaparan tersebut bahwa pemerintah desa Sukamukti dalam melakukan upaya pemberdayaan lingkungan adalah dengan mengoptimalkan 


\section{Saridera}

potensi yang ada di lingkungan masyarakat Desa Sukamukti yaitu dibidang keterampilan dengan memanfaatkan potensi dan sumber yang ada agar tertatanya lingkunganyang bersih dan masyarakat menjadi sejahtera. Dalam pengupayaan masyarakat Desa Sukamukti pemberdayaan ini memiliki beberapa tahap untuk pencapaian dari sebuah tujuan.

Dimulai dari tahapan dari proses seleksi lokasi dilakukan melalui pencarian masalah yang berada di Desa Sukamukti yaitu membludaknya tumbuhan Eceng Gondok yang tak terkendali, sampai-sampai danau Situ Bagendit terselimuti olehnya dan membuat warga sekitar menjadi resah karena dengan pertumbuhannya yang begitu pesat membuat rugi para peternak ikan, dan menjadikan danau tak terlihat indah.Dilanjut pada kegiatan sosialisasi pemberdayaan masyarakat yang dilakukan dengan mengadakan remukan masyarakatmengenai permasalahan yang berada di Desa Sukamukti berserta solusi untuk menghadapi masalah tersebut. dalam proses pemberdayaan masyarakat terbentuklah sebuah kelompok yang bernama Kiwang Kreatif dengan memanfaatkan limbah Eceng Gondok, sebagaimana hasil wawancara dengan Ibu Cucu beliau mengatakan:

Upaya yang dilakukan salah satunya dengan memanfaatkan eceng gondok. Eceng gondok ini dikelola untuk dijadikan suatu produk yang menjadi barang bernilai yaitu dengan membuat anyaman, tas dengan dan sebagainya (wawancara dengan Ibu Cucu pada tanggal 10 November 2017).

Dengan pemaparan diatas bahwa Eceng gondok dapat dimanfaatkan menjadi berbagai manfaat dan tentunya dapat menjadi sebuah barang yang bernilai. Masyarakat di daerah situ bagendit yang hususnya di kampung Kiaralawang Desa Sukamukti Kecamatan Banyuresmi Kabupaten Garut. Dari uraian tersebut memberikan gambaan bahwa komunitas Kiwang Kreatif telah bersungguh-sungguh melakukan upaya meningkatkan kualitas hidup masyarakat, yakni dengan memanfatkan sumberdaya alam yanag ada di sekitar warga desa Sukamukti.

Pemanfaatan Eceng gondok ini terinspirasi oleh komunitas Creavill atau sekelompok mahasiswa yang berasal dari Garut yang berbeda Universitas yang salah satunya di pelopori oleh saudara agung, ketika itu mereka melihat-lihat keadaan bagendit hususnya pada danaunya yang penuh dengan Eceng gondok sehingga tidak terlihat air danau tersebut, dari sini lah para mahasiswa dan sarjana terpanggil jiwanya untuk memberdayakan lingkungan menjadi bersih, dengan tidak mengabaikan tumbuhan Eceng gondok menjadi sebuah sampah atau gulma. Dari sinilah saudara agung memanggil kawan-kawannya untuk membentuk sebuah kelompok yang bernama Kiaralawang Kreatif (Kiwang Kreatif), nama Kiaralawang diambil dari nama kampung tersebut. Di mulai dari mengolah limbah Eceng gondok menjadi bahan yang bernilai menjadi sebuah 
modal utama dari kelompok Kiaralawang Kreatif untuk memberdayakan masyarakat berbasis lingkungan, dengan menggunakan program OVOP.

Dengan mengupayakan pemanfaatan lingkungan menjadi suatu kesadaran dan kepedulian terhadap lingkungan menurut Mudaham Taufick Zen bahwa usaha melibatkan setiap warga dalam menumbuhkan dan membina kesadaran untuk melestarikan lingkungan berdasarkan tata nilai, dari pada lingkungan itu sendiri dengan filsafat hidup secara damai dengan alam lingkungannya (Neolaka, 2008: 19).

Dengan begitu jelas tujuan dari para sarjana atau mahasiswa ingin memberdayakan masyarakat sekitar desa sukamukti yang berbasiskan lingkungan dengan membentuk kelompok Kiwang Kreatif. Dengan adanya upaya untuk meningkatkan kemampuan dan potensi yang dimiliki oleh masyarakat, masyarakat dapat mewujudkan jati diri, harkat dan martabatnya secara maksimal untuk bertahan dan mengembangkan diri secara mandiri baik bidang ekonomi, sosial, agama, budaya dan lain-lain.

Dengan dibentuknya sumber daya manusia sebagai pengelola lingkungan akan mewujudkan lingkungan yang bersih dan memiliki manfaat yang bernilai. Pendekatan sistem dalam pengelolaan lingkungan, meminjam konsepsi tentang relasi individu sistem dari sosiologi Amerika, Talcott Parsons, kita bisa memahami bahwa upaya penyelamatan lingkungan bisa kita lakukan melalui dua pendekatan. Pertama, mengacu pada pendekatan individu, dinyatakan bahwa baik buruk lingkungan bergantung pada perilaku individu. Kedua sebaliknya berkaitan dengan penjelasan sistem dalam kaitan dengan lingkungan, bisa dinyatakan bahwa kerusakan lingkungan tidak lepas dari pola struktur sosial dan sistem sosial dimana terbentuk dari individu/kelompok yang berinteraksi. Keberadaan Kiwang Kreatif ini, sangat menguntungkan bagi masyarakat setempat sebagaimana wawancara dengan Ibu Siti :

Alhamdulillah... setelah adanya Kiwang Kreatif ini berkat dari Komunitas Creavill manfaatnya terasa buat kita masyarakat disini. Yang dulu mah eceng gondok itu dibiarkan saja nunggu dari pemerintah kalau di bersihkan, juga kita masyarakatnya gak tau kalau ternyata bisa di gunakan atau diolah jadi sebuah kerajinan. Sekarang mah alhamdulillah berkat dari Creavill bisa lebih bermanfaat saling menguntungkan juga, buat nelayannya jadi kebantu nangkap ikannya, buat kita juga ibu-ibu kiwang jadi lebih produktif ada kegiatan juga nambah-nambah penghasilan bantu keluarga, itung-itung buat jajan anak-anak alhamdulillah cukup. Di tambah lagi jadi tambah ilmu bisa ngolah eceng gondok. (sumber wawancara dengan ketua Kiwang Kreatif, Ibu Iis pada tanggal 13 November 2017)

Pemberdayaan adalah serangkaian kegiatan untuk memperkuat kekuasaaan atau keberdayaan kelompok lemah dalam masyarakat, termasuk individu-individu 


\section{Saridera}

yang mengalami masalah kemiskinan (Suharto, 2005: 56-60).

Dalam proses pemberdayaan di masyarakat oleh Komunitas Creavill ini tidak lepas dari peran aktif masyarakatnya sendiri dalam pemberdayaan bagi mereka, hal tersebut terlihat dari kondisi di lapangan dan setelah bertemu langsung dengan masyarakat yang sudah menjadi sebuah kelompok kecil dengan nama "Kiwang Kreatif' hasil dari proses pemberdayaan yang dilakukan oleh komunitas Creavill dalam pemberdayaan melalui pengolahan potensi yang ada yaitu dari limbah Eceng gondok yang terdapat pada Situ Bagendit yang menjadi hama atau gangguan bagi para nelayan dalam mencari ikan, dimana hasil dari pemberdayaan tersebut sedikitnya membantu kepada masyarakat dalam segi ekonomi maupun keterampian dalam membuat kerajinan tangan serta membantu kepada anak-anak dalam belajar dan merekatkan rasa kekeluargaan diantar masyarakat tersebut.

Dalam pembuatan kelompok masyarakat Kiwang Kreatif ini anggota kelompok atau personil-personil yang ada di dalamnya yaitu para ibu-ibu hebat yang menjadi sukarelawan dengan jiwa sosial dan kepedulian terhadap lingkungan yang besar, beserta gabungan masyarakat yang ikut dan berpartisipasi dalam pemberdayaan potensi lokal yang berada di wilayah mereka dengan memiliki kesadaran terhadap apa yang mereka lakukan untuk membangun desanya menjadi desa yang maju.

Kesadaran merupakan keinsyafan akan perbuatanya atau keputusannya. Sadar artinya merasa, tahu, ingat (kepada keadaan yang sebenarnya), keadaan ingat akan dirinya, ingat kembali (dari pingsannya), siuman, bangun (dari tidur) ingat, tahu dan mengerti. Jadi, kesadaran adalah hati yang telah terbuka atau pikiran yang telah terbuka tentang apa yang telah dikerjakan, sehingga akan menjadikan sebuah tekad diri pada setiap individu hususnya pada kelompok masyarakat Kiwang Kreatif Desa Sukamukti dalam membangun desa yang maju.

Upaya yang dilakukan masyarakat Desa Sukamukti dalam memberdayakan lingkungan tentunya tak lepas dari adanya sebuah susunan-susunan dalam pemberdayaan masyarakat, susunan tersebut tersiri dari adanya proses seleksi lokasi, sosialisasi dan proses dalam pemberdayaan. Menurut Tim Delivery (2004) tahapan-tahapan kegiatan pemberdayaan masyarakat yang dimulai dari proses seleksi lokasi wilayah, sosialisasi pemberdayaan masyarakat, proses pemberdayaan masyarakat (Mardikanto, 2012: 125).

Hasil dari pemberdayaan yang di lakukan oleh masyarakat di Desa Sukamukti dalam memberdayakan lingkungan melalui tahapan-tahapan dalam konsep pemberdayaan masyarakat berhasil dilakukan dan berjalan dengan baik.Tahapan-tahapan itu dengan seleksi lokasi melalui pencarian sebuah masalahsosialisasi, proses dengan diadakannya remukan masyarakat untuk mencari sebuah solusi, ajakan sebagai salah satu bentuk apresiasi sampai pada pembentukkan sebuah kelompok, pemberdayaan masyarakat. 


\section{Strategi Kelompok Masyarakat Kiaralawang Kreatif}

Strategi sering diartikan dengan beragam pendekata, seperti sebagai suatu rencana,strategi merupakan pedoman atau acuan yang dijadikan landasan pelaksanaan kegiatan,demitercapainya tujuan-tujuan yang ditetapkan (Mardikanto, 2012: 167).

Dalam pencapaian strategi pada kelompok Masyarakat Kiaralawang Kreatif masing-masing individu sebagai khalifah dimuka bumi ini kita sebagai manusia yang berjiwa sosial dan peduli akan lingkungan sekitar perlu untuk memiliki potensi dalam mengelola lingkungan pada wilayah-wilayah yang memerlukan pemberdayaan lingkungan bahkan pada wilayah sekitar tempat tinggal kita. Setiap orang mempunyai hak yang sama atas lingkungan hidup yangbaik dan sehat dan hak atas informasi lingkungan hidup yang berkaitan dengan peran dan pengelolaan lingungan hidup.

Karena apabila manusia mengurus dan mengelola alam lingkungan dengan berbagai kekayaan yang tersedia ini dengan sebaik-baiknya, seadil-adilnya, maka kebaikan itu akan dinikmati manusia secara awet dan lestari. Tetapi sebaliknya, apabila pengurusan alam ini tidak baik, boros dan serampangan, tidak adil dan tidak seimbang dalam melakukan eksplorasi melewati batas dalam memprlakukan alam lingkungannya, niscaya azab Allah SWT dan malapetaka akan dating kepada manusia. Dan itu tidak lain akibat perbuatan tangan manusia itu sendiri (Mundiatun, 2015: 157).

Untuk pengelolaan lingkungan di daerah Bagendit hususnya pada Kecamatan Banyuresmi dengan menggunakan strategi yang dilakukan kelompok masyarakat Kiwang Kreatif melalui pemanfaatan limbah Eceng gondok menjadi sebuah barang yang bernilai maka dalam mencapai keberhasilan ini tentunya dari program dan upaya yang ada perlu adanya strategi yang dilakukansebagaimana yang dikatakan oleh Ibu Imas:

Strategi yang kami lakukan yaitu dengan beragamnya pelatihan, karena dengan pelatihan suatu keterampilan dapat menghasilkan sesuatu. Nah, pelatihan yang kami lakukan dengan pelatihan pembuatan anyaman dari tumbuhan Eceng gondok, kemudian pembimbingan dan pendampingan dalam pembuatan anyaman Eceng gondok, melakukan permodalan kemudian melakukan jaringan usaha(wawancara dengan Ibu Imas pada tanggal 12 November 2017)

Berdasarkan penelitian tersebut kegiatan yang dirancang untuk mengembangkan sumber daya manusia melalui rangkaian kegiatan identifikasi, pengkajian serta proses belajar yang terencana. Hal ini dilakukan melalui upaya untuk membantu mengembangkan kemampuan yang diperlukan agar dapat melaksanakan tugas, baik sekarang maupun di masa depan yang akan datang melalui pelatihan untuk membuat anyaman dari Eceng gondok sebagai strategi 
I. Saridera

pertama dalam kegiatan kelompok masyarakat Kiwang Kreatif meberdayakan lingkungan menjadi bersih dan mempunyai nilai. Strategi yang dilakukan dalam pelatihan pembuatan anyaman dari tumbuhan Eceng gondok, yaitu dengan penyediaan bahan baku anyaman eceng gondoksebagaimana yang dikatakan oleh Ibu Imas:

Dengan pembuatan anyaman ini perlu adanya penyediaan bahan baku anyaman Eceng gondok yaitu dengan cara memilih Eceng. Eceng yang digunakan yaitu Eceng gondok yang sudah tua atau panjang, kemudian diambil tangkainya, kemudian dibersihkan menggunakan sabun atau kaporit, kemudian dijemur(wawancara dengan Ibu Imas pada tanggal 12 November 2017)

Berdasarkan hal tersebut dapat mempermudah anggota Kiwang Kreatif melakukan strategi pemberdayaan masyarakat dengan memanfaatkan yang ada di alam. Untuk melakukan ini perlu adanya ketelitian, kerapihan, kebersihan agar Eceng gondok yang digunakan dapat menghasilkan anyaman yang menarik dan mempunyai nilai jual yang tinggi, produk yang dihasilkan dapat berupa tas, tempat tisu, sandal, loket, dan masih banyak lainnya.Hal ini sebagaimana yang dikatakan oleh Ibu Siti:

Kreasi yang dihasilkan oleh Kiwang Kreatif ini tentunya banyak, kita awalnya membuat tempat tisu yang mudah, kemudia tempat menyimpan buku atau dokumen, dan Alhamdulillah kita sekarang dapat memproduksi tas, sandal, pas bunga, gantungan kunci dan keranjang. Tentunya hal ini dipengaruhi oleh omset penjualan yang tinggi (wawancara dengan Ibu Siti pada tanggal 13 November 2017)

Berdasarkan hasil wawancara dengan Ibu Siti bahwa penjualanproduk dari kiwang kreatif ini menghasilkan omset yang sangat tinggi, tentunya ini bukan hanya dipengaruhi oleh barang yang unik dan menarik tetapi daya tarik konsumen juga dipengaruhi oleh perubahan sosial. Pada zaman sekarang banyak masyarakat yang memilih barang yang unik dari hasil yang mereka tidak diduga, seperti produk kiwang ini dengan memproduksi barang yang tahan, awet dengan pemanfaatan Eceng Gondok yang ada di Situ Bagendit Garut. Di Indonesia ini banyak keterampilan yang dihasilkan dari barang-barang bekas yang menjadi nilai jual yang tinggi bahkan sampai keluar negeri hal ini tentunya ada pelatihan sumber daya manusia yang meningkat pelatihan adalah proses yang didesain untuk meningkatkan pengetahuan dan ketrampilan teknis, ataupun meningkatkan kinerja pegawai. Dengan tujuan untuk mengurangi dan menghilangkan kinerja yang buruk, meningkatkan produktivitas, membentuk sikap, loyalitas, da kerja sama yang lebih menguntungkan, memenuhi kebutuhan perencanaan sumberdaya manusia, mengurangi frekuensi dan biaya kecelakaan kerja, dan membantu karyawan dalam peningkatan dan pengembangan pribadi mereka. 
Strategi-strategi yang dilakukan kiwang kreatif ini selain membuat anyaman tentunya dilatar belakangi dengan pembimbingan dan pendampingan dalam pembuatan anyaman Eceng gondok. Pembuatan anyaman ini dibimbing dan didampingi oleh seorang seniman yang dipelopori oleh seorang mahasiswa. Untuk pelaksanaannya dilakukan oleh anggota kiwang kreatifsendiri baik dari pembimbingan atau pendampingan dalam pembuatan anyaman Eceng gondok, agar dalam proses pembuatan anyaman Eceng gondok lebih berkonotasi pada menguasai, mengendalikan dan mengontrol.

Jadi, tahapan ini untuk membantu individu maupun kelompok yang berangkat dari kebutuhan dan kemampuan kelompok yang didampingi dengan mengembangkan proses interaksi dan komunikasi dari, oleh, dan untuk anggota kelompok maupun di luar anggota yaitu masyarakat yang sedang ikut berpartisipasi serta mengembangkan kesetiakawanan dan solidaritas kelompok dalam rangka tumbuhnya kesadaran sebagai manusia yang utuh, sehingga dapat berperan dalam kehidupan masyarakat sesuai dengan kemampuan yang dimiliki.Sebagaiaman yang dikatakan oleh Imas:

"produksi kiwang ini dilakukan tidak setiap hari, namun hanya dilakukan tiga hari dalam seminggu, adapun full seminggu jiga pemesanan produk banyak, dalam pendampingan pembuatannya dilakukan dengan beberapa orang ini bertujuan untuk dapat mengontrol, mengendalikan barangbarang atau bahan baku agar dapat dimanfaatkan sebaik mungkin" wawancara dengan Ibu Imas pada tanggal 15 November 2017)

Berdasarkan hal tersebut pembimbingan dan pendampingan dalam pembuatan anyaman Eceng gondok merupakan suatu solusi yang tepat untuk memproduksi hasil yang bagus dan menarik hal ini juga untuk memperbaiki kekurangan dari keterampilan setiap pekerja. Tujuan dari tahap ini adalah untuk menguji apakah pelatihan SDM tersebut efektif di dalam mencapai sasaransasarannya yang telah ditetapkan.

Dalam pandangan manusia terhadap lingkungan (ekosistem) dapat dibedakan pada dua cara pandang, yakni pandangan yang bersifat imanen (holistik) dan pandangan bersifat transenden. Dalam perspektif imanen atau holistik, posisi alam meskipun terpisah dengan manusia, namun memiliki relasi fungsional dengan faktor biofisik (hewan, tumbuhan, sungai, laut dan gunung) sehingga membentuk kesatuan sosio-biofisik. Sedangkan bagi manusia yang berpandangan transenden, menempatkan lingkungan berada pada posisi yang jauh, meskipun menyadari bahwa alam dan manusia berhubungan erat, sehingga manusia merasa terpisah dari lingkungannya. Bagi manusia seperti ini, lingkungan atau alam sekitar hanya dianggap sebagai sumber daya alam yang bebas dieksploitasi demi kepentingan umat manusia(Muhyiddin, 2010: 814-815).

Dalam pengolahan eceng gondok tentunya harus ada pelatihan. Pelatihan 
I. Saridera

dalampembuatan anyaman dari tumbuhan Eceng gondok tidak hanya dilakukan dengan menyediakan bahan-bahan namun juga perlu adanya permodalan dalam melaksanakan program dari kelompok Kiwang Kreatif. Modal atau saranasarana dalam pelaksanaan program kegiatan pemberdayaan masyarakat berbasis lingkungan dengan pemanfaatan limbah Eceng gondok melalui kelompok masyarakat Kiwang Kreatif ini di dukung oleh beberapa lembaga sebagaimana dikatakan oleh Ibu Cucu:

Kita melakukan pelatihan pembuatan anyaman ini tentunya kita sama sekali gak punya modal, maka dari itu kami melakukan kerjasama dengan yayasan mizan amanah dan dinas sosial, karena memang Kiwang Kreatif ini sudah mempunyai izin usaha dan sebagai peningkatan sumber daya manusia juga dapat meningkatkan perekonomian masyarakat (wawancara dengan Ibu Cucu pada tanggal 15 November 2017)

Kiwang Kreatif bekerjasama dengan yayasan mizan amanah yang meupakan lembaga sosial kemanusiaan nasional yang didirikan pada tanggal 19 juli 1995, yayasan ini hadir dengan tekad untuk menjadi pengelola amanah umat terdepan di tingkat nasional. Dari yayasan mizan amanah kelompok masyarakat Kiwang Kreatif mendapatkan order berupa pemesanan gantungan yang terbuat dari Eceng gondok, yang gantungan ini akan digunakan sebagai aksesoris untuk diberikan kepada para pengunjung yang datang ke yayasan mizan amanah. Selain dari pengorderan gantungan yang terbuat dari Eceng gondok yayasan mizan amanah pun menyumbangkan sebuah balai untuk kelompok masyarakat Kiwang Kreatif, sebagai tempat berkumpul, membuat anyaman, dan lain sebagainya.

Sehingga dengan keberadaan yayasan mizan amanah Kiwang Kreatif bisa terus memproduksi sebagian produk yang di kembangkan dari bahan Eceng gondok, mudah-mudahn kerjasama yang terjalin dengan yayasan mizan amanah ini bisa berkembang sehingga menjadi insfirasi yayasan atau intansi negri atupun bukan bisa tertarik untuk bekerjasama dengan Kiwang Kreatif.

Kemudian tidak hanya bekerjasama dengan yayasan mizan amanah namun dengan Dinas Sosial Kiwang Kreatif ini bekerjasama hal ini agar perkembangan kelompok masyarakat Kiwang Kreatif mulai membaik berkembangnya baik dalam membuat produk menganyam eceng gondok menjadi sebuah karya, awal mulanya sarana yang digunakan pun menggunakan cara yang manual, akan tetapi dengan ke gigihan dan keuletan Kelompok masyarakat Kiwang Kreatif dinas sosial pun mulai melirik kerjakeras Kelompok masyarakat Kiwang Kreatif, alhasil dinas sosial memberi bantuan sehingga pengelolaan produk menjadi lebih meningkat dari yang asal mula hanya menggunakan tenaga tangan para pengrajin menjadi menggunakan mesin sebagai alat bantu pembuatan anyaman, contohnya dalam pembuatan anyaman sandal.

Dengan alat bantu berupa satu set mesin jahit yang di berikan kepada kelompok masyarakat Kiwang Kreatif dari bantuan donasi Dinas Sosial, sebagai 
bentuk kepedulian dan partisipasi terhadap adanya kelompok masyarakat Kiwang Kreatif sebagai wadah yang bisa membantu perkembangan sosial dan perekonomian masyarakat Desa Sukamukti.

Selain dari adanya dukungan berupa sarana dan prasarana diatas, tentunya modal utama dalam pelaksanaan program ini yaitu adanya partisipasi dari masyarakat sekitar Desa Sukamukti untuk menjadi lebih maju terutama keinginan memberdayakan lingkungan sekitar danau bagendit agar terlepas dari marak nya tumbuhan Eceng gondok tanpa

Hakikatnya tujuan adanya trategi dalam kelompok ini yaitu untuk meningkatkan kemampuan dan kemandirian masyarakat dalam meningkatkan taraf hidupnya, dalam proses pemberdayaan tersebut masyarakat bersama-sama.

Proses pemberdayaan masyarakat: mengidentifikasi dan mengkaji potensi wilayah, permasalahan dan peluang-peluang, menyusun rencana kegiatan kelompok, menetapkan rencana kegiatan kelompok rencana yang telah disusun bersama dengan di dukung dengan fasilitas dari pendamping selanjutnya diimplementasikan dalam kegiatan yang konkrit dengan tetap memperhatikan realitas dan rencana awal, memantau proses dan hasil kegiatan secara terus menerus secara partisipatif, pemandirian masyarakat (Mardikanto 2012: 126-127)

Hasil dari strategi yang dilakukan oleh Kelompok Kiwang Kreatif dengan mengidentifikasi dan potensi wilayah melalui pemberian pelatihan dan penyuluhan, selanjutnya menyusun rencana kegiatan kelompok dengan pengorganisasian, menetapkan rencan kegiatan seperti diadakannya pelatihanpelatihan membuat anyaman dari tumbuhan Eceng Gondok dengan bimbingan husus dalam proses pembuatan, pemandirian masyarakat yang disertakan dengan pendampingan dalam setiap kegiatan sampai pada adanya perubahan yang lebih baik, baik dalam segi lingkungan ataupun dalam kesejahteraan masyarakat kampung Kiaralawang, Desa Sukamukti, Kecamatan Banyuresmi, Kabupaten Garut berjalan dengan baik.

\section{DampakPemberdayaan Masyarakat Berbasis Lingkungan Melalui Kelompok Kiaralawang Kreatif}

Menurut Otto Soemarwoto dampak adalah pengaruh yang kuat dari seseorang atau kelompok orang di dalam menjalankan tugas dan kedudukannya sesuai dengan statusnya dalam masyarakat, sehingga akan membawa akibat terhadap perubahan baik positif maupun negatif(Soemarwoto, 1998: 35).

Untuk mengetahui dampak yang dirasakan dengan adanya pemberdayaan masyarakat berbasis lingkungan di Desa Sukamukti, maka perlu diketahui indikator apakah menunjukan masyarakat berdaya atau tidak. Jika program tidak memberikan dampak yang baik terhadap perekonomian masyarakat berarti program dikatakan kurang berhasil namun juka program memberikan dampak terhadap kesejahtran masyarakat berarti program dikatakan berhasil. Kemudian 


\section{Saridera}

selain itu keberhasilan suatu program bisa dilihat dari perubahan pola pikir masyarakat dan juga kesejahteraan masyarakat.

Program yang telah di buat oleh komunitas Kiwang Kreatif dapat di katakana berhasil karena telah berdampak terhadap kesejahteraan perekonomian masyarakat dan pola pikir masyarakat. Tentunya hal tersebut tercapai atas adanya kerjasama antara pemerintah desa, dinas sosial, anggota Kiwang Kreatif dan masyarakat pada umumnya. Tanpa adanya kerjasama antara berbagi pihak tersebut program ini tidak akan berjalan dengan lancar, untuk saat ini masyarakat sudah merasakan manfaat dari adanya program tersebut dilihat dari perubahan yang terjadi di desa Sukamukti baik dibidang ekonomi, pengetahuan, dan lingkungan. Dampak yang ditimbulkan juga berpengaruh pada kenyamanan lingkungan. Sebagaimana wawancara dengan Pak Ajang selaku ketua RW:

Alhamdulillah... setelah adanya komunitas kiwang keadaan di situ bagendit menjadi bersih lingkungan, kemudian keindahan alampun mulai Nampak, serta dengan pemanfaatan eceng gondok ini hingga dibuatkan barang bernilai ini sangat berpengaruh pada aspek lingkungan dan perekonomian masyarakat (wawancara dengan Pak Ajang selaku ketua RW pada tanggal 13 November 2017).

Sebagaimana hasil wawancara tersebut,kebersihan pada lingkungan daerah situ bagendit sangatlah terasa oleh masyarakat sekitar kecamatan banyuresmi berkat adanya pemberdayaan lingkungan yang dilaksanakan oleh kelompok masyarakat Kiwang Kreatif dan pembasmian Eceng gondok yang dilakukan oleh pemerintah. Kemudian keindahan lingkunganpun tidak terlepas dari kebersihan tentunya yang melahirkan sebuah keindahan pada lingkungan sekitar Situ Bagendit khusunya Kecamatan Banyuresmi, dengan menghilangnya tanaman Eceng gondok yang membungkus keindahan dari danau situ bagendit ini.Sebagaimana menurut beberapa warga masyarakat Desa Sukamukti yaitu Ibu Dedeh:

Dengan adanya pelatihan pemanfaatan eceng gondok ini, saya pribadi bisa mendapat penghasilan, menumbuhkan kreatifitas juga dengan memanfaatkan potensi yang ada. Karena saya juga tidak menyangkan dengan Eceng gondok bisa mencetak suatu barang yang dapat menghasilkan uang (wawancara dengan Ibu Dedeh selaku masyarakat pada tanggal 13 November 2017).

Berdasarkan hasil temuan peneliti dilapangan bahwasanya pemberdayaan masyarakat berbasis lingkungan melalui kelompok Kiaralawang Kreatif (Kiwang Kreatif)dalam memberdayakan masyarakat dengan dilakukannya pelatihan pemanfaatan limbah Eceng gondok menjadi suatu barang bernilai, tentunya dalam meningkatkan kesejahteraan masyarakat sudah cukup baik walaupun sebaiknya ada yang perlu ditingkatkan, hal ini dapat terlihat dengan upaya-upaya yang dilakukan oleh pihak Kiwang Kreatif dalam mensukseskan program yang 
sedang dilakukan. Kegiatan pelatihan ini dilakukan oleh Kiwang Kreatif bekerja sama dengan dinas sosial dikatakan berhasil dilihat dari kegiatan pelatihan yang rutin yang mulai mengalami peningkatan baik dari cara masyarakat berpartisipasi aktif dengan diadakannya kegiatan ini.

Suatu pemberdayaan menunjukkan kemampuan untuk menjangkau dan mengontrol sumber-sumber dan orang-orang. Konsep yang berkaitan dengan pemberdayaan adala stratifikasi, yang menunjukkan cara-cara bagaimana kelompok-klompok orang dalam masyarakat dibeda-beda satu sama lain dan ditempatkan dalam susunan hierarkis. Sertifikasi dan hierarkis menghambat iindividu-individu dan kelompok-kelompok untuk menjangkau sumber-sumber yang berharga, kekuatan dan kontol atas mereka sendiri (Fachrudin, 2012: 68).

Pelatihan ini dilakukan sebagai salah satu upaya untuk memberdayakan masyarakat Sukamukti, karena tanpa adanya pelatihan masyarakat tidak mempunyai keahlian dalam berbagai bidang apapun. Kemudian pelatihan ini juga dapat membantu terhadap masyarakat yang sedang mangalami penurunan dalam penghasilan mereka.

Untuk mencapai kesejahteraan hidup perlu adanya dorongan dalam setiap individu, karena berdayanya seseorang dilihat dari usaha itu sendiri dalam memperoleh kesejahteraan. Dengan mengikuti keterampilan, penyuluhan terhadap peningkatan mata pencaharian hal yang vital bagi masyarakat desa sebagai proses untuk memperbaiki dan memenuhi kebutuhan hidup. Karena kebutuhan hidup ditunjang dengan pendapatan perekonomian yang mengalami peningkatan dalam setiap harinya.

Program pemberdayaan masyarakat melalui pemanfaatan lingkungan tentunya akan berhasil dilakukan apabila masyarakat menerima akan program tersebut. Program pemberdayaan lingkungan masyarakat yang dilakukan oleh Kiwang Kreatif, dapat di dorong dengan berbagai upaya maka ada hasil penunjang dari berjalannya suatu program. Hasil sebuah program di dasari dengan faktor-faktor pendukung dan faktor penghambat. Adanya faktor pendukung dari kegiatan kelompok kiwang kreatif yaitu dari berbagai jaringan usaha seperti Mizan Amanah, Dinas sosial, yang mendukung atau membantu dalam memproduksi kerajinan Eceng gondok, dan adanya partisipasi dari ibu-ibu yang aktif dalam kelompok ini.

Kesejahteraan ekonomi masyarakat mengalami peningkatan dengan banyak manfaat yang dirasakan oleh masyarakat yang mengikuti pelatihan ini. Setidaknya masyarakat menjadi ada peluang untuk membuka usaha baik itu usaha menjahit atau memasak karena mereka sudah mendapat pelatihan. Masyarakat mendapatkan penghasilan tambahan untuk mencukupi kebutuhan keluarganya dengan memanfaatkan sumber yang ada untuk menggali potensi sehingga dapat menambah penghasilan bagi pemilik usaha maupun pegawainya 


\section{Saridera}

dan, penghasilan keluarga ada peningkatan.

Namun suatu pemberdayaan masyarakat di berbagai bidang tidak terlepas dari berbagai hambatan yang menyertainya. Hambatan yang sering muncul adalah sulitnya untuk mensinergiskan berbagai pemberdayaan itu dalam suatu program yang terpadu. Dengan memusatkan pada satu dimensi, pengembangan akan mengabaikan kekayaan dan kompleksitas kehidupan manusia dan pengalaman masyarakat. Tidak ada alasan untuk mengatakan bahwa berbagai tindakan untuk memberdayakan masyarakat tidak bisa disinergiskan. Keberhasilan suatu program di dorong dengan faktor-faktor pendukung dan faktor penghambat.

Faktor penghambatnya dipengaruhi oleh keadaan sumber daya alam yang ada, akan tetapi diluar dari adanya kendala dari faktor penghambat diatas tidak menjadikan berehentinya kelompok masyarakat Kiwang Kreatif ini terus berkarya dalam pemberdayaan lingkungan melalui pemanfaatan tumbuhan Eceng gondok. Kendala yang terjadi dalam hal ini tidak mengurangi antusias dan partisipasi masyarakat untuk mencapai tingkat kesejahteraan terutama dalam peningkatan kualitas lingkungan yang bersih, nyaman, dan memberikan manfaat untuk banyak orang.

Betapa pentingnya peran manusia dalam melestarikan lingkungan sehingga peran manusia yang akan menentukan keindahan alam dan lingkungannya, menjaga keseimbangan alam, sampai pada pemanfaatan lingkungan atau alam sebagai bahan untuk pencaharian uang tanpa merugikan satu samalainnya.

Hasil dari adanya upaya masyarakat dan strategi dari Kelompok Kiwang Kreatif membuat dampak yang menjadikan lingkungan terlihat tertata dibandingkan dengan sebelumnya, melahirkan sebuah lapangan pekerjaan, membuat masyarakat menjadi lebih produktif, masyarakat lebih sejahtera karena selain dari pada itu dengan adanya kegiatan kelompok ini membuat perekonomian menjadi meningkat karena dari hasil pengolahan limbah tumbuhan Eceng Gondok memiliki nilai jual.

\section{PENUTUP}

Berdasarkan hasil dan pembahasan mengenai pemberdayaan masyarakat berbasis lingkunganmaka dapat disimpulkan sebagai berikut:Pertama, upaya yang dilakukan oleh pemberdayaan masyarakat berbasis lingkungan melalui kelompok Kiaralawang Kreatif (Kiwang Kreatif) yaitu dengan pemanfaatan Eceng gondok untuk dijadikan barang yang mempunyai nilai tinggi. Pihak aparat pemerintah setempat ikut berkontribusi dalam memberdayakan lingkungan untuk meminimalisir pencemaran lingkungan yaitu dengan memanfaatkan Eceng gondok yang ada di situ Bagendit Garut.

Kedua, strategi yang dilakukan Kiaralawang Kreatif (Kiwang Kreatif) yaitu dengan melakukan pelatihan membuat anyaman Eceng gondok, kemudian 
dilakukannya pembimbingan dan pendampingan dalam pembuatan Eceng gondok dan diadakannya anggaran atau permodalan untuk melaksanakan program Kiwang Kreatif ini. Strategi ini bertujuan untuk mencetak produk yang menarik dan mudahnya pemasaran kepada masyarakat untuk dilakukan kerjasama antara Kiwang Kreatif dengan yayasan mizan amanah dan dinas sosial.

Ketiga, dampak dari pemberdayaan masyarakat berbasis lingkungan selain teciptanya lapangan pekerjaan yang signifikan juga menjadikan masyarakat menjadi produktif. Kemudian banyak masyarakat yang mencapai kesejahteraan hidup tentu hal ini di dorong dari individu itu sendiri, karena berdayanya seseorang dilihat dari usaha itu sendiri dalam memperoleh kesejahteraan. Dengan mengikuti keterampilan, penyuluhan terhadap peningkatan mata pencaharian hal yang vital bagi masyarakat desa sebagai proses untuk memperbaiki dan memenuhi kebutuhan hidup. Karena kebutuhan hidup ditunjang dengan pendapatan perekonomian yang mengalami peningkatan dalam setiap harinya.

Berdasarkan kesimpulan dan hasil penelitian mengenai pemberdayaan masyarakat berbasis lingkungan, banyak masyarakat yang mempunyai banyak keterampilan khususnya memanfaatkan eceng gondok menjadi sebuah nilai yang berkualitas. Masyarakat Banyuresmi Garut mengalami perubahan tatanan sosial dari segi kemandirian, ketentraman hidup, kenyamanan dalam kehidupan bermasyarakat, dan meningkatkan keterampilan berpikir. Sehingga pemberdayaan dapat dilakukan dengan cara menumbuhkan lembaga-lembaga non formal dalam masyarakat.

Program Kiaralawang Kreatif(Kiwang Kreatif)merupakan program jangka menengah dan program jangka panjang, sehingga sehingga bukan hanya kebutuhan air bersih saja yang dapat di tingkatkan oleh angggota, namun kebutuhan ekonomi dan lingkungan pun dapat di tingkatkan kembali. Maka dalam hal ini perlu adanya peningkatan dalam bidang ekonomi dan lingkungan, dengan melaksanakan semua program, maka dampak terhadap masyarakatpun akan lebih meningkat. Sehingga proses pemberdayaan masyarakat akan lebih terasa oleh semua masyarakat Sukamukti umumnya masyarakat Banyuresmi Garut. Hal tersebut yang akan menjadikan masyarakat mandiri, sesuai dengan tujuan adanya pemberdayaan masyarakat. Kemudian harus adanya peningkatan dalam bidang ekonomi dan lingkungan, dengan melaksanakan semua program, agar dampak terhadap masyarakatpun akan lebih meningkat. Sehingga proses pemberdayaan masyarakat akan lebih terasa oleh semua masyarakat Sukamukti umumnya masyarkat Banyuresmi Garut. Hal tersebut yang akan menjadikan masyarakat mandiri, sesuai dengan tujuan adanya pemberdayaan masyarakat.

\section{DAFTAR PUSTAKA}

Jastam, M.S. (2015). Pemberdayaan Masyarakat Melalui Pengelolaan Sampah 
(Studi Kasus di Bank Sampah Pelita Harapan, Kelurahan Ballaparang, Kecamatan Rappocini, Makassar). Higiene, 1 (1), 42-48.

Fachrudin, A.(2012). Pengantar Ksejabteraan Sosial, Bandung: Refika Aditama.

Fua, J.L. \& Wekke, I.S. (2017). Islam dan Konservasi: Pendekatan Dakwah dalam Pelestarian Lingkungan. Al-Tahrir, 17 (2),411-432.

Hardoyono, F. (2009). Menggagas Dakwah Penyelamatan Lingkungan. KOMUNIKA , .3(1), 20-36.

Mardikanto, T. P. (2012). Pemberdayaan Masyarakat dalam Perspektif Publik, Bandung: Alpabeta.

Muhyiddin, A.(2010). Dakwah Lingkungan Perspektif Al-Qur`an, dalam Ilmu Dakwah: Academic Journal for Homiletic Studies, 5(15), 6-17.

Mundiatun, D.D. (2015). Pengelolaan Kesehatan Lingkungan. Yogyakarta: Gava Media.

Mustangin, Kusniawati, D., Islami, N.P., Setyaningrum, B., Prasetyawati, E. (2017) Pemberdayaan Masyarakat Berbasis Potensi Lokal Melalui Program Desa Wisata di Desa Bumiaji, Sosioglobal Jurnal Pemikiran dan Penelitian Sosiologi, 2 (1): 59-72.

Neolaka, A.(2008). Kesadarann Lingkungan, Jakarta : Rineka Cipta.

Nurjamilah, C (2016) Pemberdayaan Masyarakat Berbasis Masjid dalam Perspektif Dakwah Nabi SAW, Journal of Islamic Studies and Humanities, 1 (1): 93-119.

Poerwadarminta, W.J.S. (1991). Kamus Umum Bahasa Indonesia, Jakarta: Balai Pustaka. Edisi Ketiga Cetakan Keempat, 2007.

Rihlah Nur Aulia, R.N. (2017). Pengelolaan Lingkungan Berbasis Pesantren (Studi Kasus di Pondok Pesantren Nurul Hakim Lombok NTB). Hayula: Indonesian Journal of Multidisciplinary Islamic Studies, 1( 2),229-244.

Soetomo. (2006).Strategi-Strategi Pembangunan Masyarakat. Yogyakarta: Pustaka Pelajar.

Suharto,E.(2005).Membangun Masyarakat Memberdayakan Rakyat, Bandung: Refika Aditama.

Soemarwoto, O. (1998). Analisa Mengenal Dampak Lingkungan. Yogyakarta : Gadjah Mada University

Sonny, K.A.(2010).Etika Lingkungan Hidup. Jakarta: PT. Kompas Media Nusantara.

Widjajanti, K. (2011) Model Pembedayaan Masyarakat, Jurnal Ekonomi Pembangunan, 12 (1): 15-27.

Yazid, Y. \& Alhidayatillah, N. (2017). Partisipasi Masyarakat dalam Pemberdayaan Lingkungan . Jurnal RIS ALAH, 28 (1), 1-9. 